\title{
PENGARUH PENGGUNAAN MEDIA ANIMASI DALAM PEMBELAJARAN IPS TERHADAP MOTIVASI BELAJAR SISWA KELAS IV SD NEGERI MANNURUKI
}

\author{
Wahyullah Alannasir \\ Dosen PGSD Universitas Islam Makassar \\ Email : wahyullah69@gmail.com
}

\begin{abstract}
The objective of study at manuruki elementari schole greade are (1) to now the student learning motivation in social study. (2) to she if the animation media usage in social study learning of class IV SD Negeri Mannuruki? (2) how the students' motivation in learning IPS with the use of animation media Elementary School fourth grade students Mannuruki? (3) whether there is influence of media use animation in teaching social studies to students' motivation Mannuruki Elementary School fourth grade?. This research uses experimental research (true experimental design. Data collection techniques used were: observation, interviews, and questionnaires. The analisis of the data use is deskriptif to describe to proces of learning by using animation media and the student motivation, and inferential analisis is used to teks the risert hipotesis by using tetest. and The results showed that: (1) The use of animation media in teaching social studies have stages of learning in which, every meeting there are three main stages were carried out by teachers namely planning, implementation and evaluation are then designed in accordance with the steps for using media animation with both categories. (2) learning motivation of students in social study on student learning motivation, before and after learning by using animation media has increased significantly ie before the treatment is in the category enough and after treatment increased student motivation with very good category. (3) the use of the animation media influence the studens' motivation to learn at the fourth grade of mannuruki elementary school.
\end{abstract}

Keywords: Social study Learning, Animation Media, learning motivation

\begin{abstract}
ABSTRAK: Tujuan penelitian yang dilakukan di SD negeri mannurki adalah (1) untuk endeskripsikan proses pembelajaran yang menggunakan media animasi, (2) untuk mengetahui motivasi belajar siswa sebelum dan sesudah belajar IPS dalam menggunakan media animasi, (3) untuk mengetahui pengaruh media animasi terhadap motivasi siswa dalam pembelajaran IPS. Penelilian ini menggunakan desain eksperimen penuh (true experimental design) pretest post test terhadap kelompok yang sama. Populasi penelitian ini adalah siswa kelas IV tahun ajaran 2014/2015 teknik sampling yang digunakan adalah teknik random sampling data dikumpulkan dengan teknik angket wawancara, dan observasi, data dianalisis secara deskriptif dan inferensial. Hasil penelitian menunjukkan bahwa: (1) Penggunaan media animasi dalam pembelajaran IPS memiliki tahapan pembelajaran dimana, setiap pertemuan terdapat tiga tahapan utama yang dilaksanakan oleh guru yakni perencanaan, pelaksanaan dan evaluasi . (2) Motivasi belajar siswa dalam pembelajaran IPS memberikan perubahan motivasi belajar pada siswa, terlihat dari hasil motivasi belajar sebelum dan sesudah pembelajaran dengan menggunakan media animasi mengalami peningkatan yang signifikan yaitu sebelum perlakuan berada pada kategori cukup dan setelah perlakuan motivasi belajar siswa meningkat dengan kategori sangat baik. (3)Penggunaan media animasi dalam pembelajaran IPS berpengaruh terhadap motivasi belajar siswa kelas IV SDN Mannuruki.
\end{abstract}

Kata kunci: Pembelajaran IPS, Media Animasi dan motivasi belajar 


\section{PENDAHULUAN}

Pendidikan merupakan sarana penting untuk meningkatkan kualitas sumber daya manusia (SDM) dalam menjamin sebuah kemajuan suatu bangsa dan negara. Peningkatan kualitas sumber daya manusia dapat direalisasikan dalam menghadapi persaingan global sekarang ini. Melalui sistem pendidikan yang sejalan dengan itu Tirtarahardja \& La Sulo (2010: 227) mengemukakan bahwa "pendidikan mempunyai tugas menyiapkan sumber daya manusia untuk pembangunan". Oleh karena itu, peningkatan kualitas sumber daya manusia sejak dini adalah prioritas utama dalam memajukan suatu bangsa dan negara. Sehubungan dengan itu, dalam Undang-Undang Sistem Pendidikan Nasional No. 20 pasal 3 tahun 2003 yang menyatakan bahwa:

Mencerdaskan kehidupan bangsa dan mengembangkan kehidupan manusia Indonesia seutuhnya, yaitu manusia yang beriman dan bertakwa terhadap Tuhan Yang Maha Esa dan berbudi pekerti luhur, memiliki pengetahuan dan keterampilan, kesatuan jasmani dan rohani, kepribadian yang mantap dan mandiri serta rasa tanggung jawab kemasyarakatan dan kebangsaan.

Tentu saja dalam memajukan sumber daya manusia dapat meningkatkan kualitas pendidikan suatu bangsa dan negara maka dari itu, kualitas pendidikan menjadi prioritas utama suatu bangsa dan negara. Salah satu yang paling berpengaruh dalam meningkatkan sumber daya manusia yaitu tenaga pendidik dalam hal ini guru yang berperan penting dan memiliki tanggung jawab untuk mengembang tugas, begitu juga dalam mengatasi permasalahan-permasalahan yang muncul.

Kurikulum saat ini menghendaki keaktifan siswa dalam belajar, dimana guru tidak saja melakukan kegiatan mengajar tetapi guru juga berpikir bagaimana proses transfer ilmu itu terjadi, yakni bagaimana siswa dapat memahami sebuah bahan ajar untuk menguasai materi pelajaran. Hal ini sejalan dengan tujuan khusus pembelajaran IPS pada jenjang sekolah dasar sebagaimana yang tercantum dalam kurikulum IPS SD Tahun 2006 yaitu "agar peserta didik mampu mengembangkan pengetahuan dan keterampilan dasar yang berguna bagi dirinya dalam kehidupan sehari-hari”, Depdiknas (dalam Susanto, 2014: 35). Seorang guru dalam menjalankan dan mengolah proses pembelajaran di kelas sangat dituntut untuk mencapai tujuan yang diharapkan. Adapun cara yang dilakukan guru dalam pembelajaran menurut Sudjana dan Rivai (dalam Fillanio, 2013: 2) bahwa menciptakan suasana yang menyenangkan quantum learning, mengikutsertakan dan menyelesaikan masalah siswa dalam pembelajaran. Jadi dalam pelaksanaannya atau dalam proses pembelajaran sebagai seorang guru harus menciptakan suasana yang menyenangkan dan menarik.

Sampai pada saat ini, pembelajaran yang terlaksana di Sekolah Dasar terutama dalam pembelajaran ilmu pengetahuan sosial (IPS) umumnya berbasis pada behaviorisme dengan penekanan pada transfer pengetahuan dan latihan, dimana dalam transfer pengetahuan peenggunaan media pembelajaran yang kurang interaktif dan dapat menyebabkan kurangnya motivasi siswa dalam belajar. Motivasi adalah usaha yang didasari untuk mengerahkan dan menjaga tingkah seseorang agar ia terdorong untuk bertindak melakukan sesuatu, sehingga mencapai hasil atau tujuan tertentu (Alkaz, 2014). Sehubungan dengan itu Sardiman (2014: 75) menyatakan bahwa "motivasi dapat juga dikatakan serangkaian usaha untuk menyediakan kondisi-kondisi tertentu sehingga seseorang mau dan ingin melakukan sesuatu, dan bila ia tidak suka, maka akan berusaha untuk meniadakan atau mengelakkan perasaan tidak suka itu".

Berdasarkan pendapat ahli di atas dapat disimpulkan bahwa motivasi merupakan usaha yang dilakukan pada kondisi tertentu agar seseorang ingin melakukan sesuatu. Motivasi belajar akan tercipta apabila ditunjang oleh beberapa faktor, yaitu faktor internal dan faktor eksternal. Faktor internal adalalah faktor motivasi yang terjadi dalam diri seorang pelajar seperti siswa yang tanpa di perintahkan untuk membaca akan melaksanakan kegiatan membaca. sedangkan faktor eksternal adalah faktor motivasi yang diluar diri seorang pelajar antara lain: bahan ajar, guru, metode, media, dan lingkungan belajar. 
Salah satu faktor ekstrernal yang akan dibahas dalam penelitian ini adalah media pembelajaran. Munandi (dalam Fillanio, 2013: 3) mengemukakan bahwa penggunaan media yang tepat dalam pembelajaran akan meningkatkan motivasi belajar siswa dan menciptakan kesenangan dalam kegiatan belajar. Dalam hal ini, penggunaan media pembelajaran dalam proses pembelajaran dapat meningkatkan motivasi belajar siswa.

Media pembelajaran yang tepat diberikan kepada siswa sangatlah berpengaruh terhadap motivasi. Jika dalam proses pembelajaran telah memanfaatkan media, diharapkan dapat memotivasi siswa dalam belajar. Dalam meningkatkan motivasi seorang siswa, terlebih dahulu harus menciptakan kesenangan dalam belajar, dimana dalam menciptakan kesenangan siswa yaitu dengan menggunaan media animasi dalam pembelajaran. Adanya paket animasi ternyata sangat efektif dalam menunjang sistem pembelajaran dalam menggali isi informasi ilmu pengetahuan dan teknologi secara mendalam. Sejak tahun 1993 penggunaannya dalam ensiklopedia dan alat-alat di sekolah telah begitu meluas hingga mencapai $45 \%$. Bentuk animasianimasi ini lebih banyak dimanfaatkan oleh pendidik, murid, pembuat review dan tim pemasaran (Trimargono dalam Fillanio, 2013: 6). Sehubungan dengan itu, pemanfaatan media animasi dalam pembelajaran sangatlah membantu dalam hal meningkatkan motivasi siswa dalam belajar.

Berdasarkan uraian penjelasan di atas, dan apa yang terjadi dengan kondisi sekarang dalam proses pembelajaran, terutama dalam pembelajaran Ilmu Pengetahuan Sosial (IPS), dimana penggunaan media pembelajaran yang kurang interaktif dapat menyebabkan kurangnya motivasi dalam belajar. Maka dari itu, sebagai seorang guru dalam mengolah proses pembelajaran diperkenankan menggunakan media pembelajaran yang interaktif sehingga dapat meningkatkan motivasi siswa dalam belajar.

Fakta yang terjadi saat ini dalam dunia pendidikan terutama dalam pendidikan Ilmu Pengetahuan Sosial di Sekolah Dasar (SD), yaitu dalam proses pembelajaran guru masih sangat minim dalam hal penggunaan media yang inovatif seperti halnya pada hasil observasi dan wawancara yang dilakukan peneliti terhadap kepala sekolah dan guru kelas IV SD Negeri
Mannuruki Kecamatan Tamalate Kota Makassar pada tanggal 1 Desember 2014, dalam proses pembelajaran banyak ditemui pelaksanaan pembelajaran yang masih kurang variatif, yang dimana siswa kurang aktif dan kurang termotivasi dalam belajar, dikarenakan penggunaan media tidak sesuai dengan karakteristik siswa dan karakteristik materinya. Sedangkan hasil wawancara yang dilakukan peneliti yaitu banyaknya guru yang kurang mampu untuk mengoperasikan penggunaan media animasi.

Alasan mengapa peneliti mengadakan penelitian di Sekolah Dasar Negeri Mannuruki karena sekolah ini merupakan salah satu sekolah yang berada pada wilayah strategis di kota Makassar, dimana proses pembelajaran sudah bisa dikatakan sangat maju, tetapi berdasarkan hasil observasi yang telah dilakukan maka peneliti mengambil kesimpulan untuk menetapkan penelitiannya di sekolah tersebut.

Berdasarkan apa yang dijelaskan di atas maka peneliti melakukan penelitian dengan judul "Pengaruh Penggunaan Media Animasi dalam Pembelajaran IPS terhadap Motivasi Belajar Siswa Kelas IV SD Negeri Mannuruki”. Animasi yang akan dipakai oleh peneliti untuk melakukan penelitian ini adalah media animasi yang sudah jadi. Hipotesis penelitian ini adalah terdapat pengaruh proses yang signifikan penggunaan animasi terhadap motivasi belajar IPS Siswa kelas IV SD Negeri Mannuruki Makassar.

\section{METODE PENELITIAN}

Jenis penelitian yang dingunakan adalah eksperimen (true eksperiment design). Jenis penelitian ini dipilih karena rancangan ini menerapkan prosedur random dalam assigment (R) pada para partisipan untuk dimasukkan kedalam dua kelompok (A dan B) yaitu kelompok eksperimen dan kontrol.

Untuk menentukan kelas eksperimen dan kelas kontrol yaitu dengan menggabungkan kelas IVa dan kelas IVb, kemudian diberi tes motivasi belajar siswa yaitu untuk mengetahui hasil motivasi belajar siswa. Dari hasil angket motivasi belajar siswa dihasilkan motivasi belajar siswa siswa dengan dengan kategori, tinggi sedang dan rendah, dari ketiga kategori ini diambillah sebagian siswa untuk dijadikan sampel dan dibentuk menjadi kelas kontrol dan kelas eksperimen. Pada sampel yang terbentuk 
baik pada kelas eksperimen maupun kelas kontrol sebelum perlakuan diberikan tes angket motivasi belajar siswa, ini dilakukan untuk mengetahui bagaimana motivasi awal siswa. Setelah hasil motivasi belajar siswa sebelum perlakuan untuk masing-masing kelompok, maka di laksanakanlah perlakuan penggunaan media animasi dalam pembelajaran IPS pada kelompok eksperimen dan perlakuan pada penggunaan media buku dengan bantuan DLP (Display Light Proyekto) dan Laptop dalam pembelajaran IPS pada kelompok kontrol, setelah perlakuan dilaksanakan pada kelompok eksperimen dan kelompok kontrol diberikan tes angket motivasi belajar siswa. Hasil angket motivasi belajar siswa sebelum dan setelah perlakuan baik pada kelas kontrol maupun kelas eksperimen didapatkan untuk dijadikan bahan perbandingan motivasi belajar siswa.

Teknik pengumpulan data yang digunakan dalam penelitian ini adalah wawancara , angket, observasi dan, teknik pengumpulan data itu dilakukan untuk mengetahui proses pembelajaran IPS dengan menggunakan media animasi, untuk mengetahui bagaimana motivasi belajar siswa sebelum dan sesudah penggunaan media animasi dalam pembelajaran IPS, baik yang terjadi di kelas eksperimen maupun dikelas kotrol diperoleh diagnosis dapat menggunakan untuk analisis deskriptif dan teknik analisis statistik inferensial.

\section{HASIL DAN PEMBAHASAN}

\section{Hasil}

\section{Gambaran Penggunaan Media animasi dalam pembelajaran IPS}

Gambaran penggunaan media animasi dalam pembelajaran IPS dilaksanakan dengan tahapan seperti penjelasan dibawah ini:

a. Perencanaan

Pada tahap ini guru mengidentifikasi kebutuhan antara lain proses wawancara terhadap siswa atau sampel, dimana untuk mengetahui bagaimana persepsi masing-masing siswa terhadap penggunaan media animasi dalam pembelajaran IPS. Dari pertimbangan wawancara tersebut, maka peneliti bersama guru yang dikonsultasikan terhadap pembimbing mengembangkan silabus, materi, rencana pelaksanaan pembelajaran (RPP), lembar kerja siswa (LKS), lembar observasi guru dan siswa, serta menyusun butir-butir soal atau alat evaluasi siswa pada setiap pertemuan.

b. Pelaksanaan

1) Tahapan Kegiatan awal

Hasil pengamatan yang dilakukan di SDN Mannuruki tentang mekanisme kegiatan pembelajaran IPS dengan menggunakan media animasi pada tahap kegiatan awal, guru terlebih dahulu mempersiapkan kelas mulai dari perlengkapan seperti buku paket, perangkat pembelajaran antara lain RPP dan LKS, Terutama persiapan kelengkapan media pembelajaran meliputi, laptop, DLP Display Light Projector, speaker, software $C D$ animasi pembelajaran. Pada kegiatan ini guru memulai kegiatan awal seperti biasanya, membuka pelajaran dengan salam, berdoa, melakukan apersepsi dan menyampaikan tujuan pembelajaran.

2) Tahapan Kegiatan Inti

Hasil pengamatan pada tahap penyajian materi dengan menggunakan media animasi pada kegiatan ini, guru menjelaskan karakteristik media animasi kepada siswa yaitu: medianya diterbitkan oleh NN Group: MEDSA yang berbentuk $\mathrm{CD}$, didalamnya terdapat pula berbagai macam pilihan mata pelajaran dan gambar untuk menjelaskan materi pembelajaran terutama mata pelajaran IPS, kemudian guru menjelaskan cara penggunaan media animasi kepada siswa yang terdiri dari tujuh langkah yaitu pertama membuka tayangan animasi smartedu melalui aplikasi ultraISO kemudian akan muncul tampilan awal; kedua pada tampilan awal media berisi, pilihan setiap mata pelajaran, tes interaktif, BSE, cerita rakyat dan edugame; ketiga klik mata pelajaran yang akan dibahas, dalam hal ini mata pelajaran IPS; keempat akan muncul bahan materi interaktif berisi beberapa pokok bahasan pada mata pelajaran IPS; kelima klik pilihan pokok bahasan perkembangan teknologi, komunikasi dan transportasi; keenam akann muncul sub pokok bahasan dari perkembangan teknologi, komunikasi, dan transportasi yang terdiri dari empat pilihan yaitu: pengertian teknologi, perkembangan teknologi, komunikasi, dan transportasi; dan ketujuh klik keempat pilihan tersebut untuk melanjutkan materi yang akan dibahas. Dalam penjelasan penggunaan media ini siswa terlihat senang, serius dalam memperhatikan guru menjelaskan penggunaan media animasi. 
Kemudian setelah guru menjelaskan materi pelajaran dengan menggunakan media animasi, guru mengelompokkan siswa kedalam 3 kelompok yang terdiri dari 5 orang dalam 1 kelompok, setelah itu guru membagikan LKS kemasing-masing kelompok untuk dikerjakan dan membimbing siswa pada saat siswa bekerja kelompok. Setelah hasil kerja kelompok selesai siswa mempersentasekan hasil diskusi kelompok dengan menggunakan media animasi yang telah dipersiapkan oleh guru, disini siswa terlihat aktif senang dan interaktif dalam menggunakan media animasi serta mempersentasekan hasil diskusinya.

b. Evaluasi

Setelah siswa mempersentasekan hasil diskusi kelompoknya menggunakan media animasi guru mengadakan tanya jawab kepada siswa dan mempersilahkan siswa bertanya apa yang tidak dimengerti sebelum guru bertanya kembali mengenai materi yang telah dipelajari, kemudian guru bersama murid menyimpulkan materi pelajaran dan memberikan evaluasi kepada siswa serta menyampaikan pesan-pesan moral kepada siswa tentang bagaimana pentingnya dalam belajar sekaligus menutup pelajaran. Dari ketiga kegiatan ini mulai dari kegiatan awal, kegiatan inti dan kegiatan akhir pelaksanaannya terlaksana sebanyak lima kali pertemuan.

Pelaksanaan pembelajaran yang dijelaskan diatas dengan penggunaan media animasi dalam pembelajaran IPS di laksanakan sebanyak lima kali pertemuan dan ini dapat dilihat dari hasil observasi aktifitas guru dari pertemuan pertama sampai dengan pertemuan terakhir yaitu, dimana pada pertemuan pertama hasil observasi penggunaan media animasi berada pada kategori baik dengan persentase $78,33 \%$, begitu juga dengan pertemuan kedua dan ketiga dimana hasil observasi penggunaan media animasi berada pada kategori baik dengan persentase 83,33\%, sedangkan pada pertemuan keempat dan kelima hasil observasi penggunaan media animasi berada pada kategori sangat baik dengan persentase $85,88 \%$ dan $88,33 \%$. Dalam hal ini penggunaan media animasi mengalami peningkatan yang signifikan dengan rata-rata persentase sebesar $84,66 \%$ yang berada pada kategori baik.

\section{Gambaran Motivasi Belajar Siswa Dalam Pembelajaran IPS Dengan Penggunaan Media Animasi}

Data hasil perolehan nilai motivasi belajar siswa dalam pembelajaran IPS kelas IV SD Negeri Mannuruki Kota makassar, baik yang berada pada kelas kontrol maupun eksperimen dapat dilihat sebagai berikut:

a. Gambaran motivasi belajar siswa dalam pembelajaran IPS sebelum penggunaan media animasi

Berdasarkan hasil motivasi belajar siswa pada kelas eksperimen maupun kelas kontrol yaitu menunjukkan bahwa memiliki motivasi belajar yang tidak berbeda secara signifikan dimana dari 15 orang siswa terdapat 5 orang siswa yang motivasi belajarnya berada pada interval skor (32 - 40) dengan kategori sangat baik dengan persentase $(33,33 \%)$, sedangkan pada interval skor $(24-31)$ terdapat 5 orang siswa dengan kategori baik dengan kata lain persentasenya $(33,33 \%)$. pada interval skor (1623) juga terdapat 5 orang siswa dengan kategori baik dengan kata lain persentasenya $(33,33 \%)$, pada interval skor $(8-15)$ tidak terdapat siswa dengan motivasi belajarnya sangat kurang dengan kata lain persentasenya $0 \%$, untuk interval skor $(0-7)$ tidak terdapat siswa dengan motivasi belajarnya sangat kurang dengan kata lain persentasenya $0 \%$.

Hasil angket motivasi belajar siswa dalam pembelajaran IPS, sebelum pelaksanaan pembelajaran atau pretest pada kelas eksperimen yaitu rata-rata motivasi belajar siswa sebesar $(28,8)$ yang berada pada kategori cukup dengan persentase $(72 \%)$ sedangkan pada kelas kontrol rata-rata motivasi belajar siswa sebesar $(28,7)$ yang berada pada kategori cukup dengan persentase $(71,75 \%)$. Hasil ini menunjukkan dan membuktikan bahwa rata-rata motivasi belajar siswa yang dimiliki tidak berbeda secara signifikan yang masing masing berada pada kategori cukup.

b. Gambaran motivasi belajara siswa dalam pembelajaran IPS setelah penggunaan media animasi

Dari hasil motivasi belajar siswa menunjukkan bahwa pada kelas kontrol dimana dari 15 orang siswa terdapat 10 orang siswa yang 
motivasi belajarnya berada pada interval skor ( 32 - 40) dengan kategori sangat baik dengan persentase $(66,66 \%)$, sedangkan pada interval skor $(24-31)$ terdapat 5 orang siswa dengan kategori baik dengan kata lain persentasenya $(33,33 \%)$. pada interval skor $(16-23)$ tidak terdapat siswa dengan motivasi belajar sangat kurang dengan kata lain persentasenya $0 \%$, pada interval skor $(8-15)$ tidak terdapat siswa dengan motivasi belajarnya sangat kurang dengan kata lain persentasenya $0 \%$, untuk interval skor $(0-$ 7) juga tidak terdapat siswa dengan motivasi belajarnya sangat kurang dengan kata lain persentasenya $0 \%$.

Sedangkan pada kelas eksperimen yaitu dari 15 siswa yang diukur motivasi belajarnya terdapat 11 orang siswa yang motivasi belajarnya berada pada interval skor (32 - 40) dengan kategori sangat baik dengan persentase $(73,33 \%)$, sedangkan pada interval skor (24 31) terdapat 4 orang siswa dengan kategori baik dengan kata lain persentasenya $(26,66 \%)$. pada interval skor $(16-23)$ tidak terdapat siswa dengan motivasi belajar sangat kurang dengan kata lain persentasenya $0 \%$, pada interval skor $(8$ - 15) tidak terdapat siswa dengan motivasi belajarnya sangat kurang dengan kata lain persentasenya $0 \%$, untuk interval skor $(0-7)$ juga tidak terdapat siswa dengan motivasi belajarnya sangat kurang dengan kata lain persentasenya $0 \%$.

Dari penjelasan perbandingan diatas mengenai hasil distribusi frekwensi pada tabel 4.3 baik pada kelas eksperimen maupun kelas kotrol motivasi, belajar siswa mengalami peningkatan yang signifikan, tetapi peningkatan motivasi belajar siswa pada kelas yang menggunakan media animasi (kelas eksperimen) peningkatannya lebih besar dibandingkan dengan kelas yang menggunakan media buku dengan bantuan DLP (Display Light Proyektor) dan Laptop (kontrol). Hal ini didukung dengan hasil observasi aktifitas siswa pada pelaksanaan pembelajaran IPS dengan menggunakan media animasi pada setiap pertemuan, dimana pada pertemuan perrtama kegiatan siswa dalam pelaksanaan pembelajaran IPS dengan penggunaan media animasi (kelas eksperimen) berada pada kategori baik dengan persentase $76 \%$ yang mengalami peningkatan sampai pertemuan kelima dimana aktifitas siswa berada pada kategori sangat baik dengan persentase $88 \%$. Sedangkan pada kelas kontrol aktifitas belajar siswa pada pertemuan pertama berada pada kategori cukup dengan persentase $64,44 \%$ dan mengalami peningkatan aktivitas siawa pada pertemuan kelima dengan kategori baik dengan persentase $73,33 \%$.

Berdasarkan penjelasan data diatas mengenai distribusi frekwensi motivasi belajar siswa baik pada kelompok eksperimen maupun kelompok kontrol yang dimana mengalami peningkatan signifikan dan didukung dengan hasil observasi aktifitas siswa. peningkatan yang signifikan ini tidak hanya didukung dari hasil observasi aktifitas siswa tapi juga didukung dengan hasil motivasi belajar setiap kelompok sebelum dan setelah perlakuan baik pada kelas eksperimen maupun kelas kontrol yaitu, pada kelompok eksperimen nilai rata-rata hasil motivasi belajar siswa sebelum perlakuan yaitu $(28,8)$ pada kategori cukup dengan persentase $(72 \%)$ dan setelah perlakuan rata-rata hasil motivasi belajar siswa sebesar $(36,6)$ dengan kategori sangat baik dan persentase sebesar $(86,5 \%)$. Sedangkan pada kelas kontrol nilai ratarata hasil motivasi belajar siswa sebelum perlakuan yaitu $(28,7)$ pada kategori cukup dengan persentase $(71,75 \%)$ dan setelah perlakuan rata-rata hasil motivasi belajar siswa sebesar $(33,4)$ dengan kategori baik dan persentase sebesar $(83,5 \%)$.

\section{Pengaruh Penggunaan Media Animasi dalam Pembelajaran IPS Terhadap Motivasi Belajar Siswa Kelas IV}

Berdasarkan data hasil penelitian yang telah diperoleh dari motivasi belajar siswa, maka data tersebut diolah menggunakan SPSS windows versi 20,0 dan hasilnya menunjukan bahwa $t$ hitung adalah $-4,882$, df (derajat kebebasan) yaitu 14, yang menghasilkan $t$ tabel sebesar 2,145, dimana $\mathrm{H}_{0}$ diterima, jika $-\mathrm{t}$ tabel $<$ $\mathrm{t}$ hitung < $\mathrm{t}$ tabel, dan $\mathrm{H}_{0}$ ditolak, jika $\mathrm{t}$ hitung $>\mathrm{t}$ tabel atau $-\mathrm{t}$ hitung $<-\mathrm{t}$ tabel, berdasarkan hasilnya $t$ hitung $>t$ tabel maka dengan kata lain $\mathrm{H}_{0}$ ditolak. Selanjutnya nilai hasil analisis kovarian untuk data motivasi belajar siswa terlihat bahwa nilai (sig. 2-tailed) $=(0,000)$. Berdasarkan hasil yang telah diperoleh tersebut jelas bahwa nilai signifikansi < 0,05 ; dengan kata lain $\mathrm{H}_{0}$ ditolak dan, $\mathrm{Hal}$ ini Menunjukkan bahwa terdapat pengaruh penggunaan media animasi dalam pembelajaran IPS terhadap motivasi belajar siswa kelas IV SD Mannuruki. Jadi dapat diartikan bahwa dengan menggunakan media animasi dalam pembelajaran IPS dapat 
meningkatkan motivasi belajar siswa. Hal ini dikuatkan dengan nilai mean $=-5,800$, dimana ketika nilai mean bernilai negatif artinya terjadi peningkatan motivasi belajar siswa.

Uji hipotesis dengan analisis kovarian dilakukan untuk mengetahui ada atau tidaknya pengaruh penggunaan media animasi terhadap motivasi belajar siswa kls IV dalam pembelajaran IPS di SDN Mannuruki. Berdasarkan hasil uji hipotesis data menunjukan bahwa nilai hasil analisis kovarian untuk data motivasi belajar siswa terlihat bahwa nilai $\mathrm{p}$ value $(\mathrm{sig})=(0,000)$. Berarti nilai $\mathrm{p}$ value $<0,05$ atau $(\mathrm{p}<0,05)$ artinya terdapat pengaruh penggunaan media animasi terhadap motivasi belajar siswa dalam pembelajaran IPS. Jadi dapat diartikan bahwa dengan menggunakan media animasi dalam pembelajaran IPS dapat meningkatkan motivasi belajar siswa. Hal ini dikuatkan dengan nilai mean $=-5,800$, dimana ketika nilai mean bernilai negatif artinya terjadi peningkatan motivasi belajar siswa.

\section{Pembahasan}

Motivasi belajar merupakan indikator keberhasilan suatu proses pembelajaraan, banyak faktor yang mempengaruhi motivasi belajar, diantaranya faktor internal dan faktor eksternal. Salah satu faktor pendukung yang dapat mempengaruhi motivasi belajar yaitu dengan memanfaatkan atau menggunakan media pembelajaran. Penggunaan media pembelajaran sangatlah membantu dalam proses pelaksanaan pembelajaraan yang dimana, siswa akan dapat bekerja sesuai dengan kemampuannya sendiri sedangkan guru hanya mengarahkan pembelajaran untuk mencapai suatu tujuan. Hal ini sejalan dengan Mangewa (2010: 172) mengemukan bahwa manfaat media pembelajaran yaitu "menimbulkan kegairahan belajar, memungkinkan iteraksi yang lebih langsung antara peserta didik dengan lingkungan dan kenyataan serta memungkinkan peserta didik belajar sendiri-sendiri menurut kemampuan dan minatnya".

Penggunaan media pembelajaran yang tepat dalam pembelajaran akan meningkatkan motivasi belajar siswa dan menciptakan kesenangan dalam kegiatan proses pembelajaran. Sehubungan dengan pelaksanaan penelitian ini penggunaan media pembelajaran animasi dalam pembelajaran IPS sangatlah berperang aktif dalam peningkatan motivasi belajar siswa dimana siswa dapat menjadi lebih interaktif dalam proses pembelajaran. Sehubungan dengan itu Munandi (dalam Fillanio, 2013: 3) mengemukakan bahwa "penggunaan media yang tepat dalam pembelajaran akan meningkatkan motivasi belajar siswa dan menciptakan kesenangan dalam kegiatan belajar". dalam hal ini penggunaan media pembelajaran animasi dalam proses pembelajaran IPS dapat meningkatkan motivasi belajar siswa.

Pengaruh penggunaan media animasi dalam pembelajaran IPS terhadap motivasi belajar mempunyai faktor pendukung dari bagaimana pelaksanaan pembelajaran berjalan dengan baik salah satunya dari cara seorang guru dalam menggunakan media animasi, Nurdianti dkk (2015: 96) mengemukakan bahwa "guru harus merancang dan mengolah pembelajaran dengan efektif untuk mencapai tujuan yang diharapkan dalam pembelajaraan IPS sehinggah dapat membuat siswa menjadi aktif, kreatif dan merasa senang ketika mengikuti pembelajaraan".

Aktifitas guru dalam mentransfer pengetahuan kepada siswa bukan lagi sebagai sosok yang mendominasi pembelajaran, namun guru dalam melaksanakan kegiatan pembelajaran sebagai fasilitator, yang dimana guru memfasilitasi siswa dalam belajar menciptakan suasana pembelajaran yang menyenangkan dan melibatkan siswa dalam mengeluarkan pengetahuannya, sehingga siswa dapat senang, aktif dan antusias dalam belajar serta dapat meningkatkan motivasi siswa. Hal ini sejalan dengan Polya (dalam Firdaus, 2009: 107) bahwa: mengajar untuk berpikir mengharuskan guru tidak hanya memberikan informasi, ia harus menempatkan diri sesuai kondisi siswa, memahami apa yang ada dalam benak siswa. Ia harus membangun kemampuan siswa mengolah atau menggunakan informasi yang diperoleh dengan bertanya: "mengapa" dan "bagaimana", sehingga keaktifan dan keberhasilan siswa dalam memecahkan masalah akan meningkatkan rasa percaya diri mereka.

Pada proses pembelajaran dengan menggunakan media lebih menekankan agar siswa dipandang sebagai subyek belajar. Hal ini dimaksudkan agar dalam pelaksanaan pembelajaran bukan hanya guru sebagai sumber dalam belajar tetapi baik buku, media, guru dan siswa termasuk dalam sumber belajar sehingga, siswa dalam belajar menghasilkan pembelajaran 
yang lebih bermakna. Sehubungan dengan itu Mangewa, (2010: 16) meyatakan bahwa "dalam mengajar guru mengatur lingkungan sehingga terbentuk suasana yang sebaik-baiknya bagi anak didik/siswa untuk belajar. Siswa itu sendirilah yang belajar, dan guru hanya sebagai pembimbing. Maka dipergunakan segala faktor dalam lingkungan, baik buku, media/alat peraga lainnya". Dengan demikian hasil belajar yang diperoleh siswa akan lebih berkesan dan bertahan lama karena siswa berperan aktif dalam proses pembelajaran.

Penggunaan media pembelajaran merupakan faktor pendukung dimana guru dapat berperang aktif sebagi fasilitator dalam pelaksanaan proses pembelajaran. Salah satu penggunaan media pembelajaran yaitu media animasi yang merupakan media interaktif, dimana dapat membuat siswa lebih aktif dalam proses pembelajaran. Hal ini berhubungan dengan pendapat. Aqib (2013: 51) mengemukakan tentang manfaat media pembelajaran yaitu: Menyampaikan materi pembelajaran dapat diseragamkan; proses pembelajaran menjadi lebih jelas dan menarik; proses pembelajaran lebih intensif; efisiensi dalam waktu dan tenaga; meningkatkan kualitas hasil belajar anak didik; media memungkinkan proses belajar dapat dilakukan dimana saja dan kapan saja; media dapat menumbuhkan sikap positif anak didik terhadap materi dan proses belajar; dan mengubah peran guru kearah yang lebih positif dan produktif.

Kemp \& Dayton (dalam Sukiyasa, 2013: 129) juga mengemukakan bahwa manfaat media animasi diantaranya "proses pembelajaran menjadi lebih interaktif, kualitas pengajaran menjadi meningkat, sikap positif siswa terhadap apa yang dipelajari dapat ditingkatkan, dapat mengubah peran positif guru, serta membangkitkan kemauan bertindak".

Sehubungan dengan pendapat di atas dengan aktifitas guru dan siswa dalam penelitian menggunaan media animasi yaitu untuk mengelolah pelaksanaan pembelajaran harus selalu mengasah kemampuan mengajar dan meminimalisir kesalahan dalam mengelolah pembelajaran pada pertemuan sebelumnya dengan memahami apa yang ada dalam benak siswa serta meningkatkan rasa percaya diri siswa atau peserta didik menjadi lebih aktif dan antusias dalam belajar. Jadi dapat disimpulkan bahwa dengan mengasah kemampuan mengajar guru dan memperbaiki kesalahan untuk meningkatkan kemampuan mengelolah pembelajaran menggunakan media animasi, dapat mempengaruhi kegiatan atau aktifitas siswa menjadi lebih antusias, aktif dan dapat memotivasi siswa dalam pelaksanaan pembelajaran.

Pembelajaran yang menggunakan media animasi sebagai alat pembelajaran dalam pelajaran IPS, merupakan salah satu cara untuk meningkatkan motivasi belajar siswa. Bukan hanya itu dalam pelaksanaan penelitian ini peningkatan motivasi siswa diukur dari setiap indikator motivasi belajar yang terdiri dari ketekunan dalam belajar, ulet dalam menghadapi kesulitan, motivasi dan ketajaman perhatian dalam belajar, berprestasi dalam belajar, mandiri dalam belajar. Peningkatan kelima indikator motivasi ini didukung dengan perubahan aktifitas siswa dalam pelaksanaan pembelajaran yang dimana siswa semakin aktif dan antusias dalam pelaksanaan pembelajaran dikelas, sikap siswa dalam merespon guru, dan usaha menyelesaikan tugas-tugas yang diberikan oleh guru yang semakin meningkat. Peningkatan ini terlihat dari hasil observasi aktivitas siswa pada setiap pertemuan baik pada kelas yang menggunakan media animasi maupun media buku dengan bantuan DLP dan laptop.

Berdasarkan apa yang dijelaskan di atas bahwa dalam pembelajaran IPS dengan menggunakaan media animasi dapat meningkatkan motivasi belajar siswa, sehubungan dengan itu, Hamalik (dalam Arsyad, 2013: 19) mengemukakan bahwa "pemakaian media pembelajaran dalam proses belajar mengajar dapat membangkitkan keinginan dan minat yang baru, membangkitkan motivasi dan rangsangan kegiatan belajar, dan bahkan membawa pengaruh-pengaruh psikologi terhadap siswa". Sukiyasa (2013: 135) dalam temuannya berpendapat demikian bahwa "dengan menggunaan media animasi dapat meningkatkan motivasi belajar siswa".

\section{SIMPULAN DAN SARAN}

Berdasarkan rumusan masalah, tujuan penelitian, dan hasil yang diperoleh sebagaimana yang telah diuraikan pada bab sebelumnya, maka pada bagian ini disajikan kesimpulan dan saran sebagai implikasi dari hasil yang diperoleh. 
Adapun kesimpulan dan saran yang dimaksud diuraikan sebagai berikut:

a. Penggunaan media animasi dalam pembelajaran IPS memiliki tahapan pembelajaran dimana, setiap pertemuan terdapat tiga tahapan utama yang dilaksanakan oleh guru yakni perencanaan, pelaksanaan dan evaluasi yang kemudian dirancang sesuai dengan langkah-langkah penggunaan media animasi denga kategori baik

b. Motivasi belajar siswa dalam pembelajaran IPS memberikan perubahan motivasi belajar pada siswa, terlihat dari hasil motivasi belajar sebelum dan sesudah pembelajaran dengan menggunakan media animasi mengalami peningkatan yang signifikan yaitu sebelum perlakuan berada pada kategori cukup dan setelah perlakuan motivasi belajar siswa meningkat dengan kategori sangat baik.

c. Penggunaan media animasi dalam pembelajaran IPS berpengaruh secara signifikan terhadap motivasi belajar siswa kelas IV SDN Mannuruki.

Penelitian ini menyarankan kepada kepala sekolah hendaknya mendorong guru-guru melalui pelatihan-pelatihan untuk mengembangkan keterampilan dalam membuat animasi dalam pembelajaran dan kepada dinas pendidikan dapat melengkapi peralatan sekolah sehingga para guru dapat membuat animasi dengan mudah. Kemudian bagi peneliti dapat kiranya melakukan penelitian serupa untuk lebih memperluas hasil penelitian.

\section{DAFTAR RUJUKAN}

Ali, Muhammad. 2009. Pengembangan Media Pembelajaran Interaktif Mata Kuliah Medan Elekromagnetik (Online), Vol. 5 No. 1 (http://journal.uny.ac.id, Diakses 11 Mei 2015).

Alkaz, Mooza. 01 Maret 2014. Makalah Motivasi Belajar. Motivasi, (Online), (http://mooza-alkaz.blogspot.com, Diakses 26 Desember 2014).

Aqib, Zainal. 2013. Model-Model, Media, dan Strategi Pembelajaran Kontekstual (Inovatif). Bandung: Penerbit Yrama Widya.

Arsyad, Azhar. 2013. Media Pembelajaran. Jakarta: PT Raja Grafindo Persada.
Dariyo, Agoes. 2013. Dasar-Dasar Pedagogi Modern. Jakarta: PT Indeks.

Delan, Ferra J. 2012. Kategori Penilaian Ideal. (Online), (http://eprints.uny.ac.id, Diakses 30 Mei 2015).

Departemen Pendidikaan Dan Kebudayaan. 2009. Laporan Hasil Belajar Siswa Sekolah Dasar. Makassar: Depdikbud

Djamarah, Syaiful Bahri. 2002. Psikologi Belajar. Jakarta: PT Rineka Cipta.

Emzir. 2013. Metodologi Penelitian Pendidikan Kuantitatif \& Kualitatif. Jakarta: PT Raja Grafindo Persada.

Firdaus. 2009. Efektivitas Pembelajaran Kooperatif Tipe NHT Dalam Pembelajaran Matematika di SMA. Tesis. Tidak diterbitkan. Makassar: Program Pascasarjana UNM.

Fitri. 26 September 2012. Pengertian Metode Demonstrasi. Tentang Pendidikan, (Online),

(https://elfitriaskowati.bologspot.com,

Diakses 28 Agustus 2015).

Fllanio, Jeli Fransius. 2013. Efektifitas Penggunaan Pembelajaran Berbasis Komputer Model Tutorial Terhadap peningkatan hasil belajar siswa pada mata pelajaran Ilmu Pengetahuan Alam. Jurnal Pendidikan Program Pascasarjana Universitas Pendidikan Indonesia (Online),

http://jurnal.repository.upi.edu,Diakses 20 Februari 2014).

Hamzah, B.Uno. 2006. Teori Motivasi dan Pengukurannya. Jakarta: PT Bumi Aksara.

Hasrul. 2010. Penerapan multimedia. Jurnal MEDTEK, (online) vol.2.no.l( http ://www.Ft. UNM.Net/ medtek/ jurnal_medtek_vol 2, diakses 27 Mei 2015).

Mangewa, Maharuddin. 2010. Perencanaan Pembelajaran. Makassar: Badan Penerbit UNM.

Murni. 22 September 2014. Prinsip Pembelajaran di Sekolah Dasar. Tentang Pendidikan, (Online),

(murnikumaulid.bologspot.com, Diakses 28 Agustus 2015)

Muzzam. 18 Mei 2012. Motivasi Belajar: Pengertian, Ciri-ciri, dan Upaya. Motivasi belajar (Online), 
(https://muzzam.wordpress.com, Diakses 26 Desember 2014).

Nurdianti. 2015. Meningkatkan Hasil Belajar Siswa Pada Pembelajaran IPS Dengan Menggunakan Media gambar dikelas IV SD Inpres Ambesia Kecamatan Tomini (Online), Vol. 4, No. 6 (http://journal.untad.ac.id, Diakses 11 Mei 2015).

Ostoroff, Wendy, L. 2013. Cara Anak-Anak Belajar. Jakarta: PT Indeks.

Purwaningsi, Nining. 03 Januari 2014. Media Pembelajaran Audio, Visual, dan Animasi. Media Pembelajaran, (Online), (http://niningpurwaningsih18.blogspot.co m, Diakses 26 Desember 2014).

Ramli, Kamrianti. 28 Februari 2011. Kelebihan dan Kekurangan Media Animasi. Media Animasi,

(Online), (http://kamriantiramli.wordpress.com, Diakses 26 Desember 2014).

Ridwan. 2004. Belajar Mudah Penelitian. Bandung: Penerbit Alfabeta.

Rusman., Deni, K., \& Cepi, R. 2011. Pembelajaran Berbasis Teknologi Informasi dan Komunikasi. Jakarta: PT Raja Grafindo Persada.

Sardiman. 2014. Interaksi dan Motivasi Belajar Mengajar. Jakarta: PT Grafindo Persada.

Subroto, Waspodo Tjipto. 2011. Pemanfaatan Media Pembelajaran dalam Pendidikan IPS SD (Online), (http://tjiptosubroto.wordpress.com, Diakses 26 Desember 2014).

Sudrajat, Akhmad. 11 September 2012. 18 Cara Meningkatkan Motivasi Belajar Siswa. Tentang Pendidikan, (Online), (https://akhmadsudrajat.wordpress.com, Diakses 26 Desember 2014).

Sukiyasa. 2013. Pengaruh Media Animasi Terhadap Hasil Belajar Dan Motivasi Belajar Siswa Materi Sistem Kelistrikan Otomotif (Online), Vol. 3 No. 1 (http://journal.uny.ac.id, Diakses 11 Mei 2015).

Susanto, Ahmad. 2013. Teori Belajar dan Pembelajaran di Sekolah Dasar. Jakarta: PT Kharisma Putra Utama.

Susanto, Ahmad. 2014. Pengembangan Pembelajaran di IPS Sekolah Dasar. Jakarta: Prenadamedia Group.
Tirtarahardja, Umar \& Sulo La L.S. 2010. Pengantar Pendidikan. Jakarta: Direktorat Jendral Pendidikan Tinggi.

Trisnadewi. 2014. Penerapan Pembelajaran Inkuiri Berbantuan Media Audiovisual Untuk Meningkatkan Aktifitas dan Hasil Belajar IPS Siswa Kelas V SD No. 3 Tibubeneng, Kuta Utara..Jurnal PGSD, (online) vol.2.no.1 (http ://ejournal.undiksha.ac.id, diakses 26 Agustus 2015).

Vika. 20 Oktober 2012. Kajian teori pembelajaran . Tentang Pendidikan, (Online), (https://eeprintis.uny.ac.id, Diakses 28 Agustus 2015). 